\title{
SOSIALISASI MEMBACA DAN MENULIS UNTUK ANAK USIA 9-12th DENGAN FILM SEBAGAI MEDIA PEMBELAJARAN
}

\author{
Johan Faladhin, Ulmi Marsya, Jayus \\ Hubungan Masyarakat, Fakultas Ilmu Komunikasi \\ Universitas Muhammadiyah Riau \\ *Email: johanfaladhin@umri.ac.id
}

\begin{abstract}
Abstrak
Kegiatan membaca merupakan aktivitas yang dapat menstimulasi otak melalui lambanglambang tertulis mengenai informasi tertentu kemudian menalarkannya.Namun sangat disayangkan bahwa tingkat minat membaca masyarakat di Indonesia masih sangat minim. Demi meningkatkan kegemaran masyarakat untuk membaca, maka hal tersebut harus dapat ditumbuhnya sejak dini. Dengan menciptakan budaya membaca yang asik serta menyenangakan dan mudah untuk diterima oleh generasi muda. Dengan adanya tantangan perkembangan zaman yang kian cepat, sehingga semakin tergerusnya budaya membaca buku dikalangan anak-anak yang disebabkan oleh kemajuan teknologi informasi yang kian beragam, maka metode yang dilakukan untuk mensosialisasikan gemar membaca tersebut yaitu dengan menggunakan film sebagai media pembelajaran. Dengan mengupas ide-ide yang ingin disampaikan film tersebut yang kemudian dapat menstimuli keinginan anak untuk gemar membaca dan kemudian menumbuhkan kebiasaan menulis bagi anak.
\end{abstract}

Kata kunci: gemar membaca, taman baca masyarakat, film, pendidikan.

\section{PENDAHULUAN}

"Membaca adalah Jendela Dunia"

Slogan ini mungkin sering kita temukan pada instansi-instansi pendidikan untuk memotivasi siswasiswi agar giat membaca. Membaca merupakan sebuah kegiatan yang dapat membuka wawasan kita akan dunia dan ilmu pengetahuan. Semakin sering membaca, maka semakin luas pula wawasan yang akan dimiliki seseorang. Membaca juga dapat dapat membentuk pola pikir yang semakin terarah. Namun pada kenyataannya di Indonesia, tingkat minat membaca masyarakat bisa dikatakan masih sangat minim. Merujuk pada data yang diberikan oleh Central Connecticut State University dalam studi yang bertemakan "Most Littered
Country In The World" menunjukkan bahwa tingkat minat membaca di Indonesia menempati peringkat nomor 2 terbawah dari 61 nagara yang menjadi basis risetnya. Peringkat ini sangat miris ketika mengingat bahwa dari segi Infrastruktur yang mendukung kegiatan membaca, Indonesia bahkan berada diatas negara-negara Eropa. Budaya cinta membaca perlu ditanamkan sejak dini, terutama pada usia anak-anak. Anak usia dini adalah anak yang sedang dalam proses tumbuh kembang. Pada usia ini segala aspek perkembangan anak mengalami kemajuan yang sangat pesat. Aspek perkembangan yang ada pada anak usia dini meliputi aspek intelektual, fisikmotorik, sosio-emosional, bahasa, moral dan keagamaan. 
ISSN : 2550-0198

Sehingga penerapan budaya cinta membaca pada anak akan dirasa efektif. Menurut Rita Eka Izzaty, M.psi, minat membaca pada anak mengalami puncaknya pada umur 912 tahun. Selain membaca, menulis juga merupakan sebuah kegiatan yang dapat member dampak positif masyarakat. Menulis dapat mengasah kemampuan kreatifitas seseorang. Sehingga keterampilan menulis juga penting ditanamkan dalam diri seseorang sedari dini.

Sebagai kota modern, Pekanbaru merupakan salah satu kota yang konsern terhadap pembentukan minat membaca bagi warganya. Dibuktikan dengan tersedianya sarana dan prasarana yang disediakan pemerintah kota Pekanbaru untuk dapat menunjung minat membaca masyarakat. Seperti Perpustakaan kota telah menyediakan berbagai fasilitas penunjang minat baca masyarakat seperti pustaka keliling dan mendirikan beberapa TBM (Taman Bacaan Masyarakat) di kota Pekanbaru. Namun sangat disayangkan, ketersediaan fasilitas tidak memberikan efek yang signifikan terhadap peningkatan minat membaca masyarakat.

Dalam rangka meningkatkan minat membaca bagi anak, perlu juga kita lihat dari bagaimana budaya yang dianut masyarakat saat ini. Budayawan Emha Ainun Najib atau biasa disapa Cak Nun, pernah mengatakan, di Indonesia terdapat "kekeliruan" tahapan budaya yang berakibat cukup fatal, yang dimaksud tahapan budaya disini adalah dari budaya membaca ke budaya elektronik (televisi dan sejenisnya). Dengan perkembangan teknologi serta tuntutan modernitas yang cukup mengikat hingga ke level anak-anak, sehingga teknologi lama semakin ditinggalkan berikut juga budaya yang dibawanya, termasuk membaca. Anak Indonesia yang hidup dengan lingkungan modern, maka tidak akan asing dengan produk-produk industri media elektronik seperti film. Film seperti yang kita tahu, dapat membawa pesan-pesan yang dikemas dengan sedemikian rupa agar menarik minat masyarakat untuk menontonnya. Film-film dengan tema pendidikan diharapkan mampu untuk menembus pengetahuan anak bangsa mengenai betapa pentingnya pendidikan serta membaca sebagai jendela ilmu pengetahuan.

\section{METODE PENGABDIAN}

Kegiatan Pengabdian masyarakat ini mendapat dukungan dari Badan Perpustakaan dan Arsip Kota Pekanbaru, sebagai penyedia tempat di sebuah TBM (Taman Baca Masyarakat) yang berlokasi di Rumbai. Alasan pemilihan lokasi ini selain ruang yang lebih mumpuni untuk diadakan sosialisasi ini juga karena terdapat beberapa sekolah disekitarnya. Pengurus TBM juga mengaku pengunjung TBM paling banyak adalah anak-anak yang bertempat tinggal dipesisir suang Siak yang dekat dengan TBM. Metode yang dilakukan dalam Pengabdian kepada Masyarakat ini adalah metode menonton film bersama, ceramah, diskusi, tanya jawab serta praktik menulis yang dilakukan oleh para peserta dari SD 63, SD 65, SD 40, dan MI Miftahudin. Diawali dengan menonton film bersama, kemudian dilanjutkan dengan pemberian materi tentang membaca, menulis, dan review film serta dilanjutkan dengan diskusi, tanya jawab, dan praktik menulis. Kemudian diakhir acara, 
ISSN : 2550-0198

diberikan reward kepada tiga orang peserta dengan isi tulisan yang paling baik, sebagai bentuk apresiasi terhadap peserta. Adapun materi yang disampaikan adalah:

\section{Membaca}

Menurut Kolker membaca merupakan suatu proses komunikasi antara pembaca dan penulis dengan bahasa tulis. Hakekat membaca ini menurutnya ada tiga hal, yakni afektif, kognitif, dan bahasa. Perilaku afektif mengacu pada perasaan, perilaku kognitif mengacu pada pikiran, dan perilaku bahasa mengacu pada bahasa anak. Sedangkan Fredick Mc Donald dalam Burns, mengatakan bahwa membaca merupakan rangkaian respon yang kompleks, di antaranya mencakup respon kognitif, sikap dan manipulatif. Membaca tersebut dapat dibagi menjadi beberapa sub keterampilan, yang meliputi: sensori, persepsi, sekuensi, pengalaman, berpikir, belajar, asosiasi, afektif, dan konstruktif. Menurutnya, aktiivitas membaca dapat terjadi jika beberapa sub keterampilam tersebut dilakukan secara bersama-sama dalam suatu keseluruhan yang terpadu.

Materi membaca yang diberikan dalam Pengabdian kepada Masyarakat tentang Sosialisasi membaca dan menulis untuk anak usia 9-12 tahun menggunakan film sebagai media pembelajaran adalah materi tentang pengertian \& pemahaman mengenai membaca, budaya masyarakat dan tentang permasalahan minat baca masyarakat, tujuan dan manfaat membaca, serta bagaimana menumbuhkan semangat dan minat baca masyarakat terutama anak-anak diusia dini.

\section{Menulis}

Setiap aktivitas atau kegiatan mempunyai suatu tujuan tertentu yang ingin diperoleh atau disampaikan kepada orang lain, begitu pula dengan menulis. Apa yang dituangkan dalam tulisan pasti mempunyai maksud atau tujuan yang ingin disampaikan kepada pembaca. Tujuan menulis secara umum adalah memberikan arahan, menjelaskan sesuatu, menceritakan kejadian, dan meringkaskan. Tujuan lain menulis adalah agar tulisan yang dibuat dapat dibaca dan dipahami orang lain yang memunyai kesamaan pengertian terhadap bahasa yang dipergunakan.

Materi tentang Menulis dalam Pengabdian kepada Masyarakat ini adalah tentang bagaimana perlunya seseorang menuangkan ide pikirannya dalam sebuah tulisan, menumbuhkan ide tulisan dari bahan bacaan, bentuk dan jenis tulisan dalam sebuah tulis, serta contoh konten atau isi tulisan berdasarkan kategorisasi penulisan agar para peserta memahami mengenai apa yang ingin ditulis.

\section{Film Sebagai Media Pembelajaran}

Film adalah alat untuk menyampaikan berbagai pesan kepada khalayak melalui sebuah media cerita. Film juga merupakan medium ekspresi artistik sebagai suatu alat para seniman dan insan perfilman dalam rangkan mengutarakan gagasan-gagasan dan ide cerita. Secara esensial dan substansial film memiliki power yang akan berimplikasi terhadap komunikan masyarakat. 
ISSN : 2550-0198

Materi tentang Film Sebagai Media Pembelajaran ini adalah menonton film bersama tentang film inspiratif "Denias : Senandung di Atas Awan" kemudian mengajak para peserta memahami isi dari film tersebut kemudian menceritakan kembali hal yang dapat memotivasi peserta untuk dapat membangkitkan minat belajar dalam hal ini adalah membaca dan menulis.

\section{HASIL DAN PEMBAHASAN}

Bentuk kegiatan sosialisasi membaca dan menulis untuk anak 912 tahun melalui film sebagai media pembelajaran di Taman Baca Masyarakat Rumbai Pekanbaru ini memberikan pemahaman sekaligus menumbuhkan minat bagi peserta sosialisasi membaca dan menulis, dari SD 63, SD 65, SD 40, dan MI Miftahudin. Rangkaian kegiatan ini diawali dengan donasi/penggalangan buku oleh Mahasiswa Himpunan Prodi Hubungan Masyarakat, pada H2 Minggu sebelum kegiatan pelaksanaan dilakukan. Acara dilaksanakan pada hari Sabtu tanggal 26 Agustus 2017 mulai pukul 10.00 WIB hingga pukul 15.00 WIB. Pemateri terdiri dari Jayus, S..Sos, M.I.Kom, Johan Faladhin, S.I.Kom, M.I.Kom, dan Ulmi Marsya, S.I.Kom, M.A. Sedangkan pembawa acara dilakukan oleh Mahasiswa dari Himpunan Prodi Hubungan Masyarakat.

Kegiatan pertama yang dilakukan ialah menonton bersama film Denias : Senandung di Atas Awan, film yang inspiratif untuk menstimulasi peserta mempelajari nilai-nilai yang terkandung didalam film tersebut. Susana yang santai dan menyenangkan merupakan bagian dari konsep kegiatan sosialisasi ini, agar tidak jenuh dan membosankan.

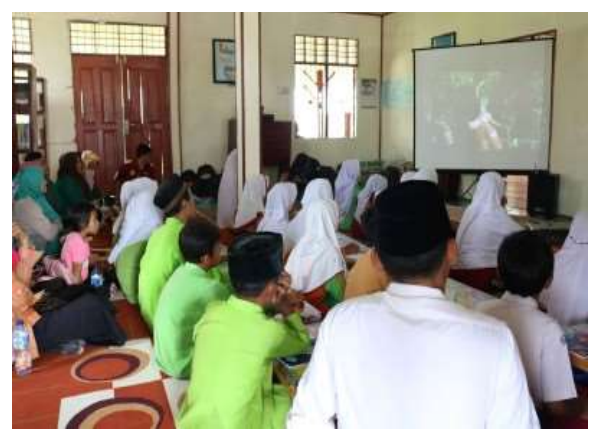

Gambar 3 : Peserta Menonton Bersama Film Denias : Senandung di Atas Awan

Kemudian setelah menonton film berakhir, dilanjutkan dengan penyampaian materi dimulai tentang materi Membacayang disampaikan oleh Ketua Pelaksana, Jayus, S.Sos, M.I.Kom. Materi ini mendapat perhatian dari peserta dan saat melakukan respon interaksi ketika Ketua Pelaksana menyampaikan tentang materi membaca.Peserta sangat antusias dalam memerhatikan materi yang disampaikan juga membuat kegiatan ini menjadi semakin meriah.

Tujuan pembinaan minat baca adalah untuk menciptakan masyarakat membaca (reading sosiety), masyarakat belajar (learning society) dalam rangka mencerdaskan kehidupan bangsa yang ditandai dengan tercipta sumber daya manusia (SDM) yang berkualitas sebagai piranti pembangunan nasional menuju masyarakat madani.

Sasaran pembinaan yang dituju adalah masyarakat secara keseluruhan dalam berbagai lapisan yang ada meliputi segala usia, jenis kelamin, jenis dan jenjang pendidikan, jenis pekerjaan atau profesi, dan sebagainya. 
Kemudian, dalam menetapkan pola pembinaan minat dan kebiasaan membaca tidak lagi memikirkan keluarga, masyarakat dan pemerintah, akan tetapi memfokuskan perhatian pada pembinaan secara khusus terhadap individu-individu dan sasaran utama adalah anak balita dan remaja, mulai anak usia 1 (satu) tahun sampai 18 (delapanbelas) tahun.

Setelah materi membaca, dilanjutkan dengan materi berikutnya membahas tentang review dalam Film Denias yang disampaikan oleh Johan Faladhin, S.I.Kom, M.I.Kom. Materi ini mengupas secara menyeluruh mengenai nilai-nilai atau pesan-pesan positif yang terdapat didalam film Denias : Senandung di Atas Awan.

Film yang berdurasi 110 menit ini dikemas dalam sebuah film drama berdasarkan kisah nyata dan terdapat beberapa unsur komedi agar menarik disaksikan. Film yang pernah meraih penghargaan Asia Pacific Screen Award for Best Children's Feature Film tahun 2007 ini, mengangkat tema tentang pendidikan, yaitu perjuangan seorang anak untuk mendapatkan pendidikan yang layak dengan usaha yang dia lakukan sehingga mendapatkan sekolah gratis. Amanat yang terkandung dalam film ini, yaitu memberikan semangat yang luar biasa dari seorang anak pedalaman Papua untuk sekolah kepada kita dan memberikan semangat untuk memperjuangkan apa yang kita inginkan.

Semangat dari para pesertapun bermunculan ketika dilakukan tanya jawab mengenai film yang related dengan materi membaca yang sudah disampaikan oleh Ketua Pelaksana, begitu juga setelah materi review film disampaikan, para peserta ditanyakan mengenai cita-cita apa yang mereka inginkan ketika mereka beranjak dewasa kelak? Ada yang menjawab ingin menjadi dokter, polwan, pilot, pengusaha, dsb. Secara tidak langsung film ini dapat menginspirasi serta memotivasi para peserta untuk berusaha dengan giat mencapai citacita yang mereka inginkan dengan rajin belajar, dengan rajin membaca dan menulis akan menambah wawasan serta memperkaya keilmuan.

Setelah materi Membaca dan review Film, acara dilanjutkan dengan penyampaian materi terakhir tentang Menulis yang disampaikan Ulmi Marsya, S.I.Kom, M.A. Materi tentang menulis diikuti dengan antusias oleh peserta. Dijelaskan oleh pemateri bahwa menulis merupakan kegiatan menuangkan ide dan suatu hal yang menarik dalam pikiran kita kepada sebuah tulisan dalam bentuk rangkaian kata.

Setelah materi tentang menulis disampaikan kemudian diadakan praktik menulis sebuah tulisan dengan tema "Memperingatu HUT RI ke 72".Para peserta diberikan waktu sekitar kurang lebih 20 menit untuk menulis sebuah tulisan dalam bentuk karangan sesuai dengan tema yang sudah ditentukan oleh panitia. Bagi tiga peserta dengan konten tulisan terbaik, panitia memberikan bentuk apresiasi berupa hadiah dalam bentuk buku, alat tulis, dan pin berikut dengan goodie bag nya.

Kemudian acara diakhiri dengan penyerahan buku secara simbolik dari pihak UMRI yang diwakilkan oleh Johan Faladhin, S.I.Kom., M.I.Kom dan penyerahan cindera mata oleh 
ISSN : 2550-0198

Ulmi Marsya, S.I.Kom.,M.A kepada pihak Dinas Arsip dan Perpustakaan Kota Pekanbaru serta diakhiri dengan foto bersama.

\section{SIMPULAN}

Meningkatkan minat membaca pada masyarakat merupakan tugas kita bersama sebagai warga negara yang baik terutaman yang bergerak di dunia pendidikan. Dengan tingginya minat membaca anak-anak di Indonesia maka kita ikut berkontribusi dalam menciptakan para generasi penerus bangsa yang lebih maju dan berwawasan luas. Dan dengan perkembangan zaman saat ini, film yang mengangkat tema-teman pendididikan rupanya bisa menjadi salah satu alat untuk membentuk minat masyarakat akan pentingnya pendidikan serta menyadari bahwa membaca sebagai jendela dunia.

\section{UCAPAN TERIMAKASIH}

Ucapan terima kasih disampaikan kepada:

1. Lembaga Penelitian dan Pengabdian Masyarakat (LPPM ) Universitas Muhammadiyah Riau (UMRI) yang telah memberikan dukungan berupa biaya dan motivasi.

2. Fakultas Ilmu Komunikasi Universitas Muhammadiyah Riau yang telah memberi dukungan agar terselenggaranya kegiatan pengabdian kepada masyarakat ini.

3. Pihak BPA (Badan Perpustakaan dan Arsip) Kota Pekanbaru. Terimakasih atas kerjasama dan apresiasinya terhadap kegiatan pengabdian ini.

4. Hima Humas Fakultas Ilmu Komunikasi Universitas
Muhammadiyah Riau. Terimakasih atas kontribusinya sebagai panitia pelaksana.

5. LSO Fikom TV Fikom Umri, terimakasih atas bantuannya dalam dokumentasi.

6. Pihak sekolah dari SD 63, SD 65, SD 40, dan MI Miftahudin. Baik guru maupun peserta acara. Terimakasih telah bersedia mengikuti acara ini hingga selesei.

\section{DAFTAR PUSTAKA}

[1] Arsyad, Azhar. 2008. Media Pembelajaran (Edisi Revisi), Jakarta: Rajawali Pers

[2] Baderi, Athaillah. 2005. Teknik Pemasyarakatan Perpustakaan dan Pembinaan Minat Baca, Jakarta: Bahan Diklat Tenaga Penyuluh Minat dan Gemar Membaca

[3] Bunanta, Murti. 2004. Buku, Mendongeng dan Minat Membaca, Jakarta: Pustaka Tangga

[4] Berger, Peter L. \& Thomas Luckmann 1990. Tafsir Sosial atas Kenyataan: Risalah tentang Sosiologi Pengetahuan (diterjemahkan dari buku asli The Social Construction of Reality oleh Hasan Basari). Jakarta: LP3ES

[5] Burns, P.C Roe, B.D., \& Ross, E.P. 1996. Teaching Reading in Today Elementary School. Boston: Houghton Mifflin.

[6] Effendy, Onong Uchjana. 2000. Ilmu Komunikasi Teori dan Praktek. Bandung : PT. Remaja Rosda Karya

[7] Gewati, Mikhael.Minat Baca di Indonesia ada Pada Urutan ke60 di Dunia, 
ISSN : 2550-0198

http://edukasi.kompas.com/rea d/2016/08/29/07175131/minat. baca.indonesia.ada.di.urutan.ke -60.dunia.diakses pada tanggal 12 May 2017

[8] Izzaty, Rita Eka.2009. Perkembangan Anak Usia 7-12 Tahun. Universitas Negri Yogyakaraka, Jurusan Psikologi Pendidikan dan Bimbingan.

[9] Kamah, Idris. 2002. Pedoman Pembinaan Minat Baca, Jakarta: Perpustakaan Nasional RI

[10] Kolker, Robert. 1983. Film, Form, and Culture. Second Ed. New York: Mc Graw Hill

[11] Profil Badan Perpustakaan dan Arsip Kota Pekanbaru Tahun 2017,

https://bpa.pekanbaru.go.id/tent ang/, diakses pada tanggal 30 Agustus 2017

[12] Santoso, Guritnaningsih. A. 2000. Studi Perkembangan Kognitif Anak Indonesia, Jakarta: Harian Kompas, Rabu, 26 Juli 2000, diakses pada jurnal dokumen.kemenag.go.id/files/ G4pKDLun1338123296, tanggal 30 Agustus 2017

[13] Suriamiharja, Agus. dkk. 1996. Petunjuk Praktis Menulis. Jakarta: Departemen
Pendidikan dan Kebudayaan Direktorat Jenderal Pendidikan Dasar Dan Menengah bagian Proyek Penataran Guru SLTP Setara D-III

[14] Syaodih, Ernawulan, Psikologi Perkembangan Anak, Universitas Negri Yogyakarta (UNY).

[15] Wibowo, Indiwan Seto Wahyu. 2011. Semiotika Komunikasi Aplikasi Praktis Bagi Penelitian dan Skripsi Komunikasi. Jakarta: Mitra Wacana Media. Merek SayHello di Kota Yogyakart. Universitas Negeri Yogyakarta. Retrieved from http://eprints.uny.ac.id/16797/1 /SKRIPSI.pdf 